\title{
Issues of 'Authenticity' and Apocalyptic Thought in an Indigenous Religious Response to Colonisation
}

\section{Introduction}

The traditional/colonial dichotomy dominates much of the discourse on New Zealand's indigenous Māori society in the nineteenth and early twentieth centuries. However, this binary distinction can often be more nuanced in practice, and in the case of certain indigenous religious responses to colonisation, can potentially obscure as much as clarify the nature of Māori society in this era. The often overlapping rather than colliding forces of the traditional and colonial worlds can be seen in religious movement led by the Māori prophet $^{1}$ and leader Rua Kēnana (1869-1937) in the early twentieth century. ${ }^{2}$

To a people that looked to be on the brink of disappearing, Rua offered the vision to his Māori followers of a utopian future (which was partly a re-fashioned image of a very vague, idealised nostalgic past) that would be achieved after the country endured various apocalypses. Rua developed his religious and prophetic movement which at its height attracted over a thousand adherents, and which anticipated rather than feared the apocalypses he prophesied because of the potential these followers felt it held for transforming their lives. What is apparent in the history of this movement is the role of colonisation as a causative and correlative element in the rise of apocalyptic religious sects, and how notions of authenticity 
can be interpreted in various ways when viewed through the optic of the group being colonised. Nether the category of traditional nor colonial applies to Rua's sect, and paradoxically, its hybridity was the source of its authenticity. The fact that it was not purely traditional or simply a transposition of settler religion is what made it authentic to Rua's followers in a period when the certainties of the preEuropean world in a state of flux, but where the world of settler society was still largely out of reach.

This paper examines the origins of Rua's sect, and how he relied increasingly on prophecies of an imminent apocalypse in order to bolster support among followers. In the course of this survey, themes of religious authenticity, the significance of cultural innovation, the role of charismatic leaders to the success of hybridised sects, and the importance of apocalyptic thought to communities in crisis are explored. What emerges from this analysis is that the tensions and dislocations of those indigenous communities in New Zealand subject to extensive colonisation was sufficiently extreme that some members of these communities sought supernatural deliverance (with the implication that the saw little prospect of temporal solutions to their situations). What is also at least circumstantially evident is that the traditional Māori world no longer fully met the religious needs of some of these communities, but to a similar extent, neither did the religious denominations of settler society either. It was in the contested space in between were movements such as those led by Rua temporarily flourished.

\section{The Social Setting of Rua Kēnana's Prophetic Sect}

The rise of Rua's religious and prophetic movement occurred against the backdrop of severe social and economic dislocation, and political and cultural marginalisation for Māori throughout the country. New Zealand was first colonised by Europeans in 1814, at a time when the Māori 
population was over $100,000 .^{3}$ However, subsequent mass immigration, predominately from Britain, drastically altered the country's demographic composition. By 1858, the settler population had risen to 59,328 , outnumbering the number of Māori, which had slumped to 55,336, and was continuing to fall. ${ }^{4}$ Ongoing epidemics if disease, a series of wars during the 1860 s, and an ensuing government programme of land confiscations, ${ }^{5}$ accelerated Māori alienation from their ancestral territories, thus depriving them of an economic base, and aggravating the poverty afflicting many Māori communities at this time. ${ }^{6}$

Compounding the bleak condition of many Māori by the close of the nineteenth century was their inadequate representation in the country's political institutions, 7 and the increasingly strong pressure - both formal and informal - on Māori to assimilate into the culture of the coloniser. ${ }^{8}$ Meanwhile, the Māori population continued to decline, reaching its nadir of 42,650 at the end of the century, which was accompanied by predictions that Māori would disappear altogether in the near future. ${ }^{9}$ It is no understatement to describe the culmination of these circumstances as an existential crisis for Māori at by turn of the century.

This impact of all these elements of Britain's colonisation of New Zealand was felt unevenly among Māori. One of the tribes which suffered the most was Tuhoe, in the eastern North Island. Crown actions in the 1860s led to what one Tuhoe elder described as the almost "complete and utter destruction" of his ancestors' community, "with a form of genocide, a scorched earth policy." 10 The Waitangi Tribunal noted that during this period, Tuhoe experienced 'substantial loss of life and large-scale disruption of settlement', 11 through punitive Crown measures which extended to burning crops and houses, killing livestock, confiscating land, desecrating graves, and forcibly evicting entire Māori communities to other areas. ${ }^{12}$ 
Given the extent of turmoil and trauma many such Māori communities were experiencing in the closing decades of the nineteenth century, it is not difficult to see how they perceived this period in apocalyptic terms. This, in turn, let to the emergence of an apocalyptic discourse among some Māori, which formed and then reinforced a collective view that some type of divine deliverance was needed from the protracted and worsening catastrophe they were experiencing. ${ }^{13}$ In their search for consolation and hope, resorting to supernatural solutions was consistent both with traditional Māori mythology (in which for example, conflicts in existing lands were resolved by deities creating new territories for people to live in, and in which the gods punished transgressions with destruction) and with the recently-introduced faith of the settlers, which also contained strong apocalyptic narratives as well as promises of redemption and deliverance. ${ }^{14}$

\section{Ringatu - the Religious Precursor to Rua's Sect}

In the context of Rua's prophetic movement, the most important religious antecedent was the Ringatu sect, founded by the Māori religious leader and resistance fighter Te Kooti Arikirangi Te Turuki [Te Kooti] (c.1832-1893). Ringatu's doctrine was the basis for Rua's sect, but perhaps even more importantly in this context, Ringatu, and the way Te Kooti led it, set a template that was emulated - unwittingly or otherwise - by Rua.

Te Kooti was known to most settlers in this era as a rebel leader who had fought the Crown, and stirred dissent among some Māori. However, his religious role was of more lasting influence in Māori society. Judith Binney's seminal work on Te Kooti identifies several significant features of his religious movement - Ringatu - which served as precursors to Rua's movement in the following century. Ringatu was ostensibly a Bible-based sect whose doctrine was altered and augmented by the Māori oral tradition, which was structured in ways that 
only loosely codified the beliefs of the sect, and which gave the sect's leader considerable flexibility in re-codifying doctrine when necessary. Te Kooti's myth-narratives also served to identify, legitimise, and thus give authority to the new prophet leaders (and thereby trumped the traditional power of chiefs, who typically did not make such appeals of quasi-divine status). The claims made by prophets such as Te Kooti, and later, Rua, gave them an autonomous source of authority that was separate from both traditional Māori power structures as well as from those of the colonisers. ${ }^{15}$

Another trait common to both sects was the means by which errors or contradictions in doctrine were resolved. Any conflict between the text (the Bible) on which the sects were based, and their interpretation by these Māori prophets was attributed to the fallible understandings of their followers rather than the error of their prophets. ${ }^{16}$ This approach enabled the doctrine of these sects to absorb (in the eyes of the devout, at least) just about any assaults launched against them that targeted contradictions or inconsistencies between the pronouncements of their prophets and the text of the Bible, or even differences in each prophet's statements over time.

The Old Testament narratives of exile were also an important element in both sects. Ringatu adopted notions of the Promised Land, the Chosen People, a covenant with God, and the idea of being strangers in the land from the stories of the Jews, and appropriated these themes for themselves. ${ }^{17}$ This identification with aspects of Old Testament history, and in particular, a sense of shared struggle in similar circumstances, gave Ringatu followers a point of identification with an oral history (which was one of the functions of oral histories for Māori) but in this instance, drawing on the oral history from another tradition.

One of the most important connections binding Ringatu to Rua's sect was that Te Kooti was seen (by his followers, at least) as a prophet who foresaw the emergence of someone like 
Rua as a spiritual successor. 18 Te Kooti had intended to build a meeting house for his followers, but never achieved this ambition. When Rua constructed his Council House at Maungapohatu, he called it Hiona [Zion] as a fulfilment of Te Kooti's wish, as well as mimicking a rough likeness of how Solomon's Temple was imagined. ${ }^{19}$ Such actions seemed to fortify the notion that Rua was the fulfilment of Te Kooti's vision for the future of his movement.

What is also significant about Ringatu, in the context of this paper, is that it appealed to those Māori who felt the need for a dynamic leader who would guide them through the middle space between the traditional Māori world, which no longer existed as it had in the pre-European period, and the colonial world that was still largely alien to many Māori, and which in some cases was openly hostile to Māori and their culture. This middle space continued to be sought after by some Māori after Te Kooti's death, and Rua managed to re-establish it in the form of his own religious, social, and political movement, which was constructed on the foundation established by his religious predecessor.

The degree of antipathy towards Ringatu shown by some Europeans persisted long after Te Kooti ceased to represent any military threat to European interest in the colony. Towards the end of the nineteenth century, the missionary William Leonard Williams attributed the creation of the Ringatu sect to a desire by its members to show defiance towards the growth of European values, culture and political influence in New Zealand. He argued that the sect's purpose "seems to have been to detach the Māori people from Christianity and so relieve them from any scruples which the profession of Christianity might cause them to entertain with reference to some of the measures which their leaders might think fit to adopt in the prosecution of War against the Pakeha [European]."20 Such a view was indicative of the failure of probably most Europeans to comprehend why some Māori became followers of Te Kooti, and similarly why they later saw 
in Rua as someone who similarly promised deliverance from their cultural and social dislocation.

\section{Authenticity}

In the face of the invasive and destructive colonisation that Tuhoe communities experienced during the latter nineteenth century, it might seem almost intuitive that they would resort to their traditional religious beliefs as a source of comfort, and as an act of opposition to the spreading religion of the colonisers. Yet, throughout this period, a number of Māori "fusion" sects emerged (possibly in excess of fifty around the country), ${ }^{21}$ which combined existing Māori religious precepts with elements of Christianity. Ringatu, and the variant of it Rua preached, were two significant examples. It is at this juncture that a paradox appears to emerge: did the infusion of the religion of the coloniser into Māori religious resistance or apocalyptic movements make the specifically religious component of those movements somehow less authentic? After all, if the appeal to Māori was to resist the coloniser, surely drawing on the coloniser's religion as part of that resistance was ideologically antithetical to such objectives?

There are several possible responses to this apparent paradox. The first is that a hybrid sect - drawing on elements from more than one religious tradition - can be regarded as authentic in so far as its construction and the selection of its elements from the religions of which it is assembled makes it a sect created in the image of its founder. To that extent, it is authentic in that it is not merely replicating any existing religion. Secondly, what constitutes authenticity is in the eye of the beholder as much as in the assessment of the outside observer. So while the fusion of two very distinct religious traditions may outwardly appear to lack cultural authenticity in the context of traditional Māori beliefs, if the followers of that sect regard it as authentic, then it must be considered as such, at least from their perspective. Another consideration 
that affects the claim of authenticity at this time is that the nature of colonial encounters - of the sort occurring in New Zealand in the nineteenth century - was one of what Tony Ballantyne has described as "entanglements," 22 which were also common elsewhere in the world where different cultures collided with each other during the process of colonisation. ${ }^{23}$ Edward Said identified the entanglement of intellectual production and cultural identity as a feature or symptom of colonisation. ${ }^{24}$ Authenticity in such a setting is undergoing a constant process of definition and redefinition in response to the evolving tensions in the colonised state. The binary of traditional-indigenous and introduced-colonised knowledge breaks down at the first point of exchange between the two groups, as do the previous certainties about what constitutes authenticity.

Roger Kessing adds additional dimensions to notions of authenticity in colonial settings, observing initially that even among indigenous groups, depictions of pre-colonial pasts and the ensuing counter-colonial movements were essentially derivative of Western ideologies. Drawing on Gramsci, he notes that counter-hegemonic discourse draws on the premises and categories of hegemonic discourses. Part of the reason for this is that the discourse of domination emerges as an objective "through which claims to power must be expressed," and cites the case of religion as one of those fields where this has been apparent.25 Patterns of Rua's religiopolitical movement can be interpreted as conforming to the tendency to orient an authentic religious sect within parameters inadvertently defined by the coloniser.

The fact that indigenous cultures - in colonial periods particularly - can tend to represent themselves in ways and in a language that has been shaped by perceptions of the dominant colonial power affects not only what authenticity is, but how it is defined. Indigenous movements can also end up identifying what is important about their own identity, what is unique about their cultural background, and what is 
authentic in both categories in a manner that focuses on differentiating them from colonisers. ${ }^{26}$

Given such perspectives on authenticity, developing a definition of what constitutes authentic indigeneity in a colonial context cannot be achieved in an objective manner. In the absence of an objective measure, the self-identification of what defines authenticity by the indigenous group can suffice as a substitute. Thus, in the setting of this paper, the sect created by Rua is deemed to be an authentic Māori religious movement (notwithstanding its nominally Christian foundation) on the basis that its followers identified it as such.

\section{Authenticity in Innovation: Rua's Sect}

Rua had been an active member of the Ringatu sect as a youth, 27 which not only gave him a (nominally Māori) faith to follow, but which also enabled him to develop his skills as an orator and a healer, in the tradition of tohunga - a group who were a central component of pre-European Māori social structure, and who continued to practice (in diminishing numbers) into the twentieth century. ${ }^{28}$ However, the turning point in Rua's life as a religious leader and prophet came in the mid-1900s, when he announced that he was Te Kooti's successor, and the Māori messiah. ${ }^{29}$ In quick succession, he claimed to fulfil the prophecies Te Kooti had left regarding a successor, 30 and then assumed the role of the leader of his own branch of Ringatu (known as Iharaira - the Israelites - as he identified himself and his followers as sharing the "Chosen People" and exiled status of their Old Testament namesake) rather than the Ringatu sect as a whole. This departure from traditional orthodox Māori religion and towards a hybridised sect which incorporated Christian elements produced a tension which reflected in some ways the tension of Māori caught up in the colonisation process at this time. This theme of tension remained throughout the life of Rua's sect, and to 
some extent made it a more authentic choice for his followers than any "purely" Māori or European religious offering.

In 1904, Rua claimed that Christ appeared before him on Maungapohatu (a sacred mountain for Tuhoe) and led him and his wife to a diamond that had been concealed in a swamp by Te Kooti, and that would supposedly one day be the means of redemption for his followers. ${ }^{31}$ This episode would have resonated strongly with those Māori in the region who were familiar with the Bible. ${ }^{32}$ In particular, the image of a prophet ascending a mountain and then returning with insights was one that appears frequently in the Old Testament, and would have strengthened Rua's claim not only as a prophet, but also as someone with divine powers. And the fact that this occurred on Maungapohatu, which was tapu (sacred) to Tuhoe, and which was where the bodies of countless ancestors were interred, made the account acquire a traditional layer of sanctity as well - fusing the traditional with elements of the introduced in Māori society.

However, while he was prepared to leverage off traditional notions of tapu, Rua did not accept the strictures of tapu unquestioningly. On occasion, he deliberately broke rules about access to certain sacred sites and violated certain practices deemed to be tapu on the basis that it demonstrated his ability to defy traditional Māori deities, and therefore elevated his status to that of a saviour of Māori (in the way that he depicted Christ as being a saviour of Europeans). ${ }^{33}$ Rua also encouraged his followers similarly to flaunt traditional conventions in order to liberate themselves from the old gods and their strictures.

After this event, some Māori in the region responded to Rua's call to join him in forming a community. What lent authenticity to Rua's religious movement, as far as his followers were concerned, was that it was neither traditionally Māori (in so far as he challenged the traditional authority of tribal chiefs and of aspects of tapu) nor was it a supporter of the country's government. ${ }^{34}$ Yet, it drew on the sacred role of a 
tohunga, which Rua had been regarded by others as well before this period, and so the roots of traditional Māori spirituality nourished Rua's embryonic sect that at once embodied and subverted these traditional indigenous beliefs.

As his number of followers swelled from the dozens to the hundreds during the 1900 s, Rua combined his messianic selfprojection with more temporal ambitions, focussing on making his new community self-sufficient. Maungapohatu became his "City of God," from where he directed a large-scale farming exercise as well as issuing prophetic statements. ${ }^{35}$ And as long as the community continued to grow and there was relative prosperity experienced by its members, the doctrinal and prophetic elements underlying Rua's sect held currency for his followers.

Rua's first major prophecy, and one that gained national interest given its content, was that he would meet the British monarch, Edward VII in Gisborne on 25 June 1906, and that the King would give him gold, diamonds, or millions of pounds in cash to purchase more land for his settlement. ${ }^{36}$ The problem with such a prophecy was the imminent date of its expected fulfilment. Rua travelled to Gisborne for the appointed day, but when it passed without the King arriving, he revised the date at least twice before finally declaring that, in fact, he was the king. ${ }^{37}$

On the face of it, the failure of the initial prophecy to materialise could have heralded the end of Rua's credibility as a prophet, and the disbanding of his community. ${ }^{38}$ However, the fact that he managed to secure and even augment his status among many of those Māori following this episode is indicative of the crisis some Māori were experiencing at the time - one in which neither their own traditions nor the world of the coloniser accommodated their sense of identity, or the fears they harboured over what still loomed in front of them as the imminent disappearance of Māori as an ethnic group. This existential apocalypse, the numerous signs of which Rua's followers would have readily seen, left them with little 


\section{Issues of 'Authenticity' and Apocalyptic Thought in an Indigenous Religious Response to Colonisation}

confidence in the traditional Māori or modern European worlds. Of the social, religious, and even economic choices before them, those offered by Rua came across as the most authentic, in part because they gave meaning to the lives of his followers, and possibly even instilled with them the sense that they were part of a religious movement that controlled circumstances rather than was controlled by them. And Rua's prophecies were central to this perception that he was in control of the future. No other Māori or European organisation seemed to offer this type of certainty at the time. Despite almost a century of Protestant and Catholic evangelisation in New Zealand, those Māori attracted to Rua's sect saw its tenets and leader as embodying particularly their apprehensions of an apocalyptic future, while also offering them salvation from the abyss of the disappearance of Māori as an indigenous group.

While the attempt at the combination of two distinct religious traditions created plenty of room for doctrinal conflict, Rua largely circumvented this by elevating his own role to that of the sole spiritual and temporal leader of his movement, and eventually, one of its deity. Rua was the Mihaia (Messiah) and depicted himself both as the final king in the line extending to King David in the Old Testament, and to earlier Māori prophets. Rua both constructed and embodied the confluence of the two faiths, and so was able to define the doctrinal parameters of his sect, and adjust them whenever required. One such shift in the rules of the sect occurred in 1915, when Rua returned to Maungapohatu after having been in prison for three months for selling whiskey without a licence. ${ }^{39} \mathrm{He}$ lifted former restrictions on people being able to live away from the community at Maungapohatu, and removed the tapu from most of the sites he had earlier declared sacred. 40

What lent authenticity to Rua's religious movement, as far as his followers were concerned, was that on the one hand, he was able to demonstrate the authority to challenge the 
traditional dominion of tribal chiefs, and the traditional beliefs relating to the sanctity of places and practices), while on the other hand, he was able to proclaim openly his defiance of the country's government and the religion of the settlers. ${ }^{41}$ Coupled with this sense of singular authenticity that Rua's followers experienced in his sect was a seam of apocalyptic pronouncements from the prophet which signalled a new development in its doctrine - one that anticipated dramatic change in the status of the world and therefore the lives of his followers. However, because of the nature and contextualisation of the apocalypse Rua predicted, it was anticipated rather than feared among members of the sect because it promised a transformative change to their circumstances.

\section{Apocalyptic Elements in Rua's Prophecies}

The media has certainly had some effect on popular perceptions of what constitutes an apocalypse, 42 but the literature on the topic encompasses more tempered definitions. It can be as undramatic as a (usually religious) revelation, and can be framed in oblique language, using symbolism rather than literalism to convey the essence of the apocalyptic message. 43 In some cases, the themes of an apocalyptic prophecy are of more importance than the precise details of how the apocalypse will unfold.

Rua's apocalyptic prophecies combined modified Christian symbolism with indigenous motifs, and appealed to his followers both as an authentic blueprint for the future, and confirmation that Rua was the only person who was able to secure their own fates during the coming convulsions that he prophesied.

As Rua evolved the way he saw himself - from being a prophet of God to being a brother of Christ - to too did his prophesies become more apocalyptic. One of the first indications of a revelation of something dramatic being predicted by Rua 


\section{Issues of 'Authenticity' and Apocalyptic Thought in an Indigenous}

Religious Response to Colonisation

occurred in 1916, during the First World War, when he annouced that the Germans would be victorious, and that his followers would prosper when New Zealand fell under German rule. ${ }^{44}$ While not promising a cataclysm of the sort that appear in popular notions of an apocalypse, Rua was certainly suggesting that something culturally, socially, and politically revolutionary was about to happen (to the extent that authorities at the time regarded it as seditious). 45

In 1927, Rua proclaimed that the end of the world was about to occur. In the face of a gradually dwindling number of followers, ${ }^{46}$ such an apocalyptic prophesy - especially one destined to take place in the very near future - served to firm up the faith of the members of his community. On 3 March 1927, the Horowhenua Chronicle reported on this prophecy, noting that Rua had

made the announcement that there will be two weeks of total darkness sometime before the end of next May, and then the heavens will be riven asunder by lightning and a deluge will follow, inundating the whole country until every living thing at Waimana/Ruatoki, Whakatane, and Opotiki will be drowned. The only safe refuge, the prophet adds, will be at Maungapohatu, when he is now collecting all the faithful. Already about 2000 Māoris are trekking there, sacrificing their money for the purchase of stores and galvanised iron, for Rua decrees that they must not live in tents, as lightning will destroy everything inflammable. ${ }^{47}$

Rua also predicted that the stars would fall from the sky, and that Christ would return to be reunited with Rua, his brother. In the following months, Rua and his adherents engaged in intense Bible study, with no-one permitted to leave the community for more than a single night. And in case the 
prophesy did not come to pass (something that Rua had already experienced with his failed prediction that Edward VII would meet him in Gisborne in 1906), he inserted a caveat, that if the world did not end as he described, it would certainly happen by the year 2000, which would give the community extra time to prepare for the apocalypse. ${ }^{48}$

Binney, Chaplin, and Wallace have argued that Rua "used fear to manipulate his people," and that the faith of his followers "needed to be fortified by fear of the unknown in order to defeat present despair." And in his prophesies about the forthcoming apocalypse, he reiterated that his followers were to be the chosen people who would be saved. ${ }^{49}$ The complete annihilation Rua forecast also extended to the oppressive power structures that many Māori experienced in the country, and so to this extent, the coming apocalypse was a political as well as religious concept, offering temporal liberation as well as spiritual salvation. As one Tuhoe elder later explained it, "[w]hen Rua became a prophet, the people were in darkness, and his dreams were to elevate the mana and the way the people lived, so that they could live again." 50

\section{The Role of Apocalyptic Thought}

The apocalyptic elements in Rua's religious teachings, when looked at in a historically linear sequence, grew more pronounced as time progressed, as did his role in the prophesied apocalypse: from a prophet; to some sort of mouthpiece of God; to a Christ himself. However, far from this growing extremity in his beliefs and pronouncements driving away followers and deterring potential members, the effect was the reverse. One of the explanations for this is that Rua's specific prophesies about the end of the world fed into his followers' apocalyptic imagination. The prophecies gave meaning to their present circumstances, particularly the tensions they experienced and the struggles they faced, by contextualising these as a "prototype of the ultimate decisive 
struggle between good and evil and its final resolution," usually through some sort of world-ending or world-changing cataclysm. In this worldview dominated by belief in an imminent apocalypse, events could be interpreted as signs of the approaching end. And even though such events were open to a much more conventional interpretation - as simply part of the tail-end of the process of New Zealand's colonisation, they were experienced by Rua's followers in a deterministic psychological sense in a way that gave them apocalyptic meaning. ${ }^{51}$

Determinism lies at the heart of this view of an apocalypse, in that the future is already mapped out (in this case, by Rua as prophet) and that all the events and circumstances his followers experienced were analogous to a script being played out. However, within the determinist approach to an apocalypse is room for a historicist conception, in which an apocalypse is linked to the destiny of a collective in this world, rather than the salvation of individuals in the next. ${ }^{52}$ In both cases though, there is a tendency to see the world in stark terms of right or wrong, good and bad, us and them. There tends to be no room for moral ambiguity or intellectual uncertainty. 53 Such certainties appeal even more to groups who may be experiencing cultural uncertainty or fragmentation, ${ }^{54}$ of the sort Rua's followers were in this period, as demonstrated by their implicit repudiation of aspects of the traditional Māori world from which they had emerged (as well as a correlative rejection of the European world which was well-established by now in the country). Thus, Rua's apocalyptic movement functioned on the basis of a fusion of his religious teachings and prophetic pronouncements with the specific social, cultural, political, and psychological factors 55 that prevailed at that time in the region.

The other element that had a bearing on the success (albeit limited in scale and tenure) of Rua's apocalyptic movement was the fact that it occurred in an agrarian community. Eric Hobsbawm's analysis of millenarian movements (whose 
followers similarly believed in impending social upheaval to be accomplished through divine agency) identified three main characteristics of such movements. These were a rejection of the present world and the longing for an alternative one to be accomplished through some radical transformation or revolution, an ideology which emphasises a coming golden age, and finally a vagueness about the precise means by which this new society will be brought about. 56 Not only do these traits conform to those of Rua's sect, but as Hobsbawm emphasised, they tended to apply almost exclusively to rural societies. 57 The community at Maungapohatu was a prime candidate for this type of millenarian movement, in that it was isolated, rural, vulnerable, poor, in a state of political, cultural, and religious upheaval, and separated in various ways from traditional certainties that only a few generations earlier were taken for granted.

The prophecy narrative of the sort Rua produced served an additional function: to provide an "imaginative framework" for explaining the way things were, and in doing so, to offer a sense of fulfilment to those who believed in the prophecies. 58 As neither the European nor the traditional Māori world individually seemed to offer and answers to the struggles of the era, prophecy - crafted as a response to the circumstances of the present - was an antidote.

\section{Conclusion}

The timing of Rua Kēnana's ascent as a prophet and religious leader was crucial to the success and form of the Iharaira sect that he founded. His followers, as well as tens of thousands of other Māori in the country, were in a state of economic and social despair in this era. By 1906, when Rua commenced his prophetic movement, almost seventy per cent of Māori land had been lost, 59 the population was at its lowest point in recorded history, disease was still rampant in many Māori communities, 60 and political representation in the nation's 
branches of government was still inadequate. The consequence of this culmination of circumstances was that in several areas of the country, the prospects for Māori looked bleak. Indeed, the possibility of Māori disappearing as a race was still one had some currency at the start of the twentieth century.

Rua's success as a prophet and religious leader from this time hinged in part on the despondent condition of many Māori. A specific aspect of this condition was that the certainties in the pre-European world had been shaken for Māori, while at the same time, the world of the European settler remained largely alien. In such an environment, the notion of what constitutes authenticity has the potential to be subverted from preexisting definitions. In such a state of flux, the authenticity of social and religious movements is likely to reflect the broader nature of society at the time. Given that the colonisation process of New Zealand had been underway for more than eight decades by the beginning of the twentieth century, the culturally and socially hybrid nature of New Zealand society was reflected in the hybridity of the religious doctrine of Iharaira and its prophet. It was authentic because it mirrored the authenticity of the racial, cultural and social entanglements taking place in the country in this period. The argument can also be made that the circumstantial evidence for this authenticity lay in the fact that at one stage Rua was able to claim over a thousand followers, whose conviction it was that Rua's pronouncements were absolutely authentic (to the extent that they were prepared to move to the community he established and live under the guidelines he determined). The ability of Rua to sustain this authenticity depended in part on his capacity to frame what constituted the nature of an ideal society (ironically) increasingly in terms of what settler society offered in areas such as material progress and political dominance. This suggests that authenticity is not an absolute set of principles of precepts, but rather, is something that resonates in the minds of those who believe something to be 
authentic. It is therefore amenable to change over time and among different groups.

With the mantle of authenticity that Rua established, he was able to build on his earlier prophecies with increasingly more dramatic predictions about the future, ranging from a German occupation of New Zealand after the First World War (and the accompanying return of land to Māori), through to a claim that the county was on the verge of an apocalypse that would bring destruction on everyone except Rua's followers. This determinist approach to the future was indicative of the technique of providing people with a sense of certainty about what lies ahead - a message that was invested with even more potency during this period of upheaval. The salvation of individuals as more closely than ever tied to the teachings of the prophet, which had the effect of galvanising Rua's support, at least in the short term.

However, the religious movement that Rua founded, and the community that coalesced around the prophet, was overwhelmingly dependent on its leader. After Rua's death in 1937, the Iharaira sect, which was already in a state of decline, shed most of its members. ${ }^{61}$ The apocalypse that Rua predicted did not eventuate, but for the period he was alive, the hope that such prophesies offered to his followers - as a resolution to the economic and emotional hardships they were enduring - served to ensure that his religious movement flourished and met the needs of its members in a manner than none of the other religious groups in the country was able to achieve at that time. 


\section{Notes}

1 For the definition of a prophet in this context, see Michael Adas, Prophets of Rebellion: Millenarian Protest Movements Against the European Colonial Order (North Carolina: University of North Carolina Press, 2012), xx.

2 A summary version of aspects of this article appears in the Journal of Indigenous Research, 2020.

3 Alexandra A. Brewis, Maureen A. Molloy, and Douglas G. Sutton, "Modeling the prehistoric Māori population," American Journal of Physical Anthropology 81, no. 3 (1990): 343.

4 Statistics New Zealand, Principal Results for 1858 Census, Aboriginal Native Population - Appendix H, (Wellington: Statistics New Zealand, 2016), n.p.

5 Bryan Gilling, "Raupatu: The Punitive Confiscation of Māori land in the 1860s," in Raupatu: The Confiscation of Mãori Land, eds. Richard Boast and Richard Hill (Wellington: Victoria University Press, 2009), 13-30.

6 Stuart Banner, "Two Properties, One Land: Law and Space in Nineteenth-Century New Zealand," Law \& Social Inquiry 24, no. 4 (1999): 807-852; Wanganui Herald, 19 October 1874, 2; Francis D. Fenton, Observations on the State of the Aboriginal Inhabitants of New Zealand (Auckland: W. C. Wilson, 1859), 31; Alan Ward, A Show of Justice: Racial Amalgamation in Nineteenth Century New Zealand (Toronto: University of Toronto Pres, 1973) 267, 297.

7 Paul Moon, “'A proud thing to have recorded': The origins and commencement of national indigenous political representation in New Zealand through the 1867 Māori Representation Act," Journal of New Zealand Studies 16 (2013): 58-62.

8 Rawiri Taonui, "Mana tamariki: Cultural alienation," AlterNative: An international journal of indigenous peoples 6, no. 3 (2011): 188189; 'Reports from Native Officers', in Appendices to the Journals of the House of Representatives (Wellington: New Zealand Government, 1882), 12; 'Reports from Native Medical Officers', in Appendices to the Journals of the House of Representatives, Wellington: New Zealand Government, 1885), 12.

$9 \quad$ M. P. Keith. Sorrenson, "Land Purchase Methods and their Effect on Māori Population, 1865 - 1901," Journal of the Polynesian Society 65, no. 3 (September 1956): 183; John Stenhouse, “'A disappearing race before we came here' - Doctor Alfred Kingcome Newman, the dying Māori, and Victorian scientific racism," New Zealand Journal of History 30, no. 2 (1996): 124-133; Manawatu Standard, 3 March 1884, 2; Walter Buller "The Decrease of the Māori Race," New Zealand Journal of Science 2 (1884): 55; Te Aroha News, 5 April 1884, 5.

10 Waitangi Tribunal, Te Urewera, Pt. 2, Wai-894 (Wellington: Waitangi Tribunal, 2010), 53.

11 Ibid., 63. 
Anita Miles, Te Urewera, working paper (Wellington: Waitangi Tribunal, 1999), 176.

Such responses are raised in Stephen D. O'Leary, Arguing the Apocalypse: A Theory of Millennial Rhetoric (Oxford: Oxford University Press, 1998), 4-7.

Margaret Orbell, "The religious significance of Māori migration traditions," Journal of the Polynesian Society 84, no. 3 (1975): 341-347; Ben Finney, "Myth, experiment, and the reinvention of Polynesian voyaging," American Anthropologist 93, no. 2 (1991): 383-404; David L. Barr, "The Apocalypse as a Symbolic Transformation of the World: A Literary Analysis," Union Seminary Review 38 no. 1 (1984): 39-50; Stanley E. Porter, "The language of the Apocalypse in recent discussion," New Testament Studies 35 no. 4 (1989): 582-603.

Judith Binney, "Myth and explanation in the Ringatū tradition: Some aspects of the leadership of Te Kooti Arikirangi Te Turuki and Rua Kēnana Hepetipa," Journal of the Polynesian Society 93 no. 4 (1984), 345.

Ibid., 347.

Ibid., 350

Ibid., 358-9.

Ibid., 376-7.

William L Williams, in Frederic W. Williams, Through Ninety Years: 1826-1916, Life and Work Among the Māoris in New Zealand. Notes of the Lives of William and William Leonard Williams, First and Third Bishops of Waiapu (Auckland: Whitcombe and Tombs, 1939), 64-5.

James Belich, Making Peoples: A History of New Zealand from Polynesian Settlement to the End of the Nineteenth Century (Auckland: Allen Lane, 1996) 220; Judith Binney, Redemption Songs: A Life of Te Kooti Arikirangi Te Turuki (Auckland: Auckland University Press, 1995), 1.

Tony Ballantyne, Entanglements of Empire: Missionaries, Māori, and the Question of the Body (Auckland: Auckland University Press, 2014), 1-14.

3 Haydon Cherry, "Digging up the past: Prehistory and the weight of the present in Vietnam," Journal of Vietnamese Studies 4 no. 1 (2009): 84-144.

4 Edward Said, "Orientalism reconsidered," Race \& Class 27 no. 2 (1985): 1-15; "Narrative, geography and interpretation," New Left Review 180 (1990): 83; William D. Hart, Edward Said and the religious effects of culture (Cambridge: Cambridge University Press, 2000), 170.

5 Roger M. Keesing, "Creating the past: Custom and identity in the contemporary Pacific," The Contemporary Pacific (Spring/Fall 1989): 22-4.

Ibid., 22-24 
27 Adrian Leske, "The Role of the Tohunga-Past and Present," Religious Studies and Theology 26 no. 2 (2007): 135.

28 Malcolm Voyce, "Māori healers in New Zealand: The Tohunga Suppression Act 1907," Oceania 60 no. 2 (1989): 99-123.

29 Judith Binney, "The Ringatu Traditions of Predictive History," Journal of the Polynesian Society, 23 no. 2 (Oct 1988), 168. Allan Hanson, "Christian branches, Māori roots: the cult of Rua," History of Religions 30 no. 2 (1990): 154-178.

30 Judith Binney, "Myth and Explanation in the Ringatu Tradition: Some Aspects of the Leadership of Te Kooti Arikirangi Te Turuki and Rua Kēnana Hepetipa," Journal of the Polynesian Society 93 no. 4 (Dec 1984): 356-7.

31 Waitangi Tribunal, Te Urewera, 15-16; Binney, Redemption Songs, 506-509.

32 Hanson, "Christian branches, Māori roots," 157-8.

33 Judith Binney, Gillian Chaplin and Craig Wallace, Mihaia: the prophet Rua Kēnana and his community at Maungapohatu (Oxford: Oxford University Press, 1979), 25.

34 Waitangi Tribunal, Te Urewera, 47-8.

35 Ibid., 48.

36 Binney, Redemption Songs, 506-509; Peter Webster, Rua and the Māori Millennium (Wellington: Victoria University Press, 1979), 163.

37 Webster, Rua, 167-168; Binney, Chaplin, and Wallace, Mihaia, 29-30.

38 For the counter-intuitive response of followers to failed prophecies, see Lorne Dawson, "When prophecy fails and faith persists: A theoretical overview," Nova Religio: The Journal of Alternative and Emergent Religions 3 no. 1 (1999): 60-82.

39 Wairarapa Daily Times, 3 July 1916, 3.

40 Hanson, "Christian branches, Māori roots," 168-9.

41 Waitangi Tribunal, Te Urewera, 47-8.

42 Peter McLaren, "George Bush, apocalypse sometime soon, and the American imperium," Cultural Studies? Critical Methodologies 2 no. 3 (2002): 327-333; Eugene Peterson, "Apocalypse: The medium is the message," Theology Today 26 no. 2 (1969): 133141.

43 Job Y. Jindo, "On myth and history in prophetic and apocalyptic eschatology," Vetus Testamentum 55 no. 3 (2005): 412-415; Graham Davies, "Apocalyptic and historiography," Journal for the Study of the Old Testament 3 no. 5 (1978): 15-28.

44 Auckland Star (29 January 1916), 6.

45 Waitangi Tribunal, Te Urewera, 44.

46 New Zealand Herald, supplement (19 March 1932), 1.

47 Horowhenua Chronicle (3 March 1927), 5

48 Hanson, "Christian branches, Māori roots," 172-3.

49 Binney, Chaplin, and Wallace, Mihaia, 63-4; Webster, Rua, 197.

50 Waitangi Tribunal, Te Urewera, 18. 
51 Millennium, Messiahs, and Mayhem: Contemporary Apocalyptic Movements eds.. Thomas Robbins, and Susan J. Palmer (New York: Psychology Press, 1997), 5.

52 Ibid., 6.

53 O'Leary, Arguing the Apocalypse, 71.

54 Dick Anthony and Thomas Robbins, "Religious Totalism, Exemplary Dualism, and the Waco Tragedy," in Millennium, Messiahs, and Mayhem, eds. Robbins and Palmer, 261-284

55 Lester Carabbe, "The social setting of early Jewish apocalypticism," Journal for the Study of the Pseudepigrapha 2 no. 4 (1989): 27-47.

56 Eric Hobsbawn, Primitive Rebels: Studies in Archaic Forms of Social Movement in the Nineteenth and Twentieth Centuries (Manchester: Manchester University Press, 1959), 57-8.

57 Michael Barkum, "Millenarianism in the Modern World," Theory and Society 1 (July 1974): 117.

58 Judith Binney, "When the white kawau flies," in Myth and Memory: Stories of Indigenous-European Contact, ed. John S Lutz (Vancouver: UBC Press, 2007), 140.

59 Tanira Kingi, "Māori landownership and land management in New Zealand," Making Land Work 2 (2008): 129-151.

60 Raeburn Lange, May the People Live: A History of Mãori Health Development 1900-1920 (Auckland: Auckland University Press, 1999), 18-40.

61 Binney, Chaplin, and Wallace, Mihaia, 175-180. 